\title{
And Mintzberg discovered Brazil: the internationalization of an executive master's program
}

\author{
SERGIO WANDERLEY ${ }^{2}$ \\ ANA Beatriz MORAES ${ }^{1}$ \\ BIANCA SÁ ${ }^{3}$ \\ ${ }^{1}$ FACULDADES IBMEC, RIO DE JANEIRO - RJ, BRAZIL \\ 2 UNIVERSIDADE DO GRANDE RIO (UNIGRANRIO), RIO DE JANEIRO - RJ, BRAZIL \\ ${ }^{3}$ Fundação Getulio Vargas (FGV EBAPE) / Escola Brasileira de AdMinistração Pública e de EMpresas, Rio de JANEIRO - RJ, BRAZIL
}

ana Christina Celano Teixeira ${ }^{1}$

\begin{abstract}
This research analyzes the International Master's Program for Managers (IMPM) internationalization process through a partnership established with a Brazilian Higher Education Institution. IMPM was conceived by Henry Mintzberg in 1996 as a program strong enough to challenge traditional American MBA programs since Mintzberg proposes that "managers not MBAs" should prevail. A critical perspective is adopted here to investigate whether the IMPM privileges an Anglo-Saxon point of view or not. We used a qualitative approach involving ninety-six in-depth interviews with faculty members and directors from both institutions responsible for establishing this partnership and carrying out the Brazilian module of the program, eight of which are addressed in this paper. Professor Henry Mintzberg was one of the interviewees. The findings show that despite all the efforts to preserve local culture, an Anglo-Saxon logic prevails, and there is an imbalance between the initial proposition and the results. There are a lot of unexplored issues to solve considering this framework, and future studies should consider and propose the recognition of the local production of knowledge and cultural diversity as key elements for the success of international partnerships.
\end{abstract}

Keywords: MBAs. Henry Mintzberg. Brazil. Local knowledge. Education in Administration.

\section{E Mintzberg descobriu o Brasil: a internacionalização de um programa de mestrado executivo}

\section{Resumo}

Esta pesquisa analisa o processo de internacionalização do International Master Program for Managers (IMPM) por meio de uma parceria estabelecida com uma Instituição de Ensino Superior brasileira. O IMPM foi concebido por Henry Mintzberg, em 1996, como um programa forte o suficiente para desafiar os programas tradicionais de MBA da América do Norte, uma vez que Mintzberg propõe que os "Managers, Not MBAs" devem prevalecer. É adotada uma perspectiva crítica para investigar se o IMPM privilegia o ponto de vista anglo-saxão ou não. A fim de atingir esse objetivo, foi utilizada uma abordagem qualitativa, com noventa e seis entrevistas em profundidade com docentes e diretores de ambas as instituições responsáveis pelo estabelecimento da parceria e pela realização do módulo Brasil do programa, neste artigo, nós abordamos oito dessas. O professor Henry Mintzberg está entre os entrevistados. Os resultados mostram que, apesar de todos os esforços para preservar as culturas locais, a lógica anglo-saxônica prevalece e existe um desequilíbrio entre a proposição inicial e os resultados. Há muitas questões inexploradas a serem resolvidas considerando essa estrutura e isso sugere que estudos futuros considerem e proponham o reconhecimento da produção local de conhecimento e da diversidade cultural como elementos-chave para o sucesso de parcerias internacionais.

Palavras-chave: MBAs. Henry Mintzberg. Brasil. Conhecimento local. Educação em administração.

\section{Y Mintzberg descubrió Brasil: la internacionalización de un programa de maestría ejecutiva}

\section{Resumen}

Esta investigación analiza el proceso de internacionalización del International Master Program for Managers (IMPM), a través de una asociación establecida con una institución brasileña de educación superior. El IMPM fue concebido por Henry Mintzberg, en 1996, para ser un programa suficientemente fuerte como para desafiar a los programas tradicionales de MBA de América del Norte, ya que Mintzberg propone que prevalezcan los "Gerentes, no los MBA". Se adoptó una perspectiva crítica para investigar si el IMPM privilegia el punto de vista anglosajón o no. Para lograr este objetivo, se utilizó un enfoque cualitativo, con ocho entrevistas en profundidad con docentes y directores de las dos instituciones responsables de establecer la asociación y llevar a cabo el módulo del programa realizado en Brasil. El propio profesor Henry Mintzberg es uno de los entrevistados. Los resultados muestran que, a pesar de todos los esfuerzos por preservar las culturas locales, prevalece la lógica anglosajona y existe un desequilibrio entre la propuesta inicial y los resultados. Hay muchas problemas inexplorados por resolver teniendo esta estructura en cuestión y esto sugiere que los estudios futuros consideren y propongan el reconocimiento de la producción local de conocimiento y la diversidad cultural como elementos clave para el éxito de las asociaciones internacionales.

Palabras clave: MBA. Henry Mintzberg. Brasil. Conocimiento local. Educación en administración. 


\section{INTRODUCTION}

Asymmetries in the production and dissemination of Management and Organizational Knowledge (MOK) have been the object of investigation of scholars from the center (e.g., Cummings \& Bridgman, 2016; Murphy \& Zhu, 2012), as well as scholars from the periphery (Alcadipani, 2017; Wanderley \& Barros, 2018). Both sides agree that MOK production and dissemination tends to privilege the Anglo-Saxon world over all other geographies.

Therefore, it is necessary to notice an increasing phenomenon in terms of the establishment of international partnerships between higher education institutions (HEI) on either side of the center-periphery division (Alcadipani \& Rosa, 2011). The current global market in higher education seems to demand more dynamic exchanges and interactions between both sides of this division. Hence, $\mathrm{HEl}$ from central countries have been seeking partnerships with similar institutions from emerging or peripheral countries (Mignolo, 2011).

According to Banerjee and Linstead (2004), we are experiencing, in fact, an increasingly global and informed era, but one which at the same time is shaped by neoliberal economic thinking. Thus, the definition of who or what constitutes "the international other" depends on who is asking the questions and, often, these questions are lost in the research on international management, especially when it does not consider the relationships characterized by asymmetries of power found in the international context (Alcadipani \& Faria, 2014; Mir \& Mir, 2013).

Even though there is a perception that neoliberal thinking remains alive in the relations between nations, companies and people, the depletion of this interaction format supported by this model has been emphasized by Mignolo (2017). The westernization of the world can no longer take place on the same basis as individuals begin to resist the time and labor patterns of contemporary corporations. Accordingly, this is a clear warning that questions the excessive submission of individuals and seeks to recover their autonomy in making decisions for themselves (Mignolo, 2017).

Within the perspective of this research, globalization, modernity, coloniality and domination always appear to be intertwined and transversal since these concepts interwoven in an indistinct manner. In terms of the concept of domination, a large portion of power theories treat this process in the same way that actors establish influence through the construction of ideological values that become hegemonic (or dominant). Fleming and Spicer $(2007,2014)$ argue that there is little coercion or manipulation openly occurring in this face of power. Instead, domination as a dimension of power "shapes our own political preferences, attitudes, and perspectives" (Fleming \& Spicer, 2007, p. 19). This idea is based on Lukes (2005), known for his "radical vision" of power, which considers power to be a political activity that defines the very ground on which political actors understand their situation within the world system.

This perspective informs how we deal in this article with the phenomenon of the establishment of partnerships between HEI on either side of the center-periphery division. The aim of this study is to verify how the process of establishing an international partnership has taken place. The partnership was established in 2012 between the International Master's Program for Managers (IMPM), an international master's degree created in 1995 and directed by Henry Mintzberg, with a Brazilian HEl. It has established an academic partnership that involves the annual completion of one of the five modules during a two-week program in the city of Rio de Janeiro under the co-responsibility of the local HEI.

To achieve this goal, a qualitative approach has been used, with eight in-depth interviews with faculty members and directors from Fundação Getulio Vargas/EBAPE and Lancaster University, institutions responsible for establishing the partnership and carrying out the Brazilian module of the program. Professor Henry Mintzberg is among the interviewees.

The relevance of this research is based on a discussion by several authors about the internationalization processes of management education programs (Celano \& Guedes, 2013; Cunliffe \& Linstead, 2009; Mintzberg \& Gosling, 2002; Zajda, 2005). The records indicate, in a recurrent way, the existence of a route for emerging countries, mainly Brazil, India and China, and asymmetries between central and peripheral countries within broader processes of management education (Alcadipani, 2017). Given this, it is necessary to take a closer look at the understanding of the dynamics that specifically involve these countries, within the context of a new global design, regarding the displacement of knowledge in management within the configuration of today's world (Hurrell, 2010). 


\section{Mintzberg's IMPM since 1996}

Henry Mintzberg and Jonathan Gosling proposed and created the IMPM in 1996, with the commitment to consider not only consumption, but also the existence of local management expertise on a world stage. Its conception may be considered pioneering when compared to the other international management programs, since it is one of the first to begin its performance in the international field, establishing partnerships with HEI in several countries (Mintzberg, 2005).

Thus, the IMPM is an international master's degree program for experienced executives, which has adopted a course model that has been adapting to world configurations for twenty years. This fact can be observed from its changing partners over time, and it currently operates in five countries, three of which are emerging: India (from the beginning of the program in 1996), China (since 2011) and Brazil (since 2012).

The five countries that took part in the first cycle of the program were: Canada, the United Kingdom, India, Japan and France ${ }^{1}$. From the outset, the IMPM was created with the proposal to work in a balanced way with partner institutions: the Indian Institute of Management in Bangalore (IIMB); INSEAD in Fontainebleau, France; the University of Lancaster Faculty of Management in the United Kingdom; the McGill University's Faculty of Management in Montreal, Canada; and in Japan, a group of professors from three institutions, Hitsosubashi University, Kobe University and the Japanese Advanced Institute of Science and Technology (later also the South Korea Development Institute in Seoul).

The program operates based on periods called cycles. Each cycle lasts eighteen months and runs two-week face-to-face classes in each of the partner countries at three-month intervals. After these 18 months, participants can choose to write a master's thesis to obtain their master's degree. This degree may be accredited by the universities of McGill and Lancaster, or by only one of them.

The program's season in each country is called a module and a 'mindset', or mental model, is assigned to each of them, which aims to relate local concepts of the host country to management learning. Since the beginning of the program in 1996, the mindsets have remained unchanged and are currently matched to the partner countries as follows: United Kingdom/ reflection, Canada/ analysis, India/ worldview, China/ collaboration, Brazil/ action.

\section{Globalization, emerging countries and the new global scenario}

Globalization seems to be experienced in many places as a discriminatory and oppressive force influencing countries on many fronts, including the fields of management and education (Banerjje, 2017; Faria, 2011; Soudien, 2005). The rise of emerging economies - such as Brazil, Russia, China and India - has had implications for the production, dissemination and consumption of knowledge (Hurrell, 2010; Soudien, 2005).

This scenario brings to light the need to understand the mechanisms involved in asymmetric power relationships. In this sense, there have been many attempts to map the different forms that power assumes in organizations (Clegg et al., 2006; Pfeffer, 2004). One of the most striking distinctions in the literature regards episodic power theories (the direct exercise of power) and systematic forms of influence (power that is frozen in more enduring institutional structures) (Clegg, 1989).

In this case, domination represents one of the faces of power that, from this perspective, can be considered systemic, insofar as it mobilizes institutional, ideological and discursive resources in influencing organizational activity. As such, it acts less as a visible face and more in terms of explicit acts of power (Fleming \& Spicer, 2014).

A portion of organizational power theories deal with the process of domination by considering the way in which actors support themselves to establish influence by constructing ideological values that become hegemonic. Fleming and Spicer $(2007,2014)$ argue that there is little coercion or manipulation occurring openly in terms of the face of power. Instead, domination as a dimension of power tends to shape alleged preferences, attitudes, and even political perspectives (Fleming \& Spicer, 2007).

\footnotetext{
${ }^{1}$ Website: http://www.impm.org/program
} 
Lukes (2005) also understands power as a political activity capable of defining the very terrain in which the actors involved in the power game understand their organizational situation:

\footnotetext{
"It is not the supreme and insidious exercise of power that can prevent people, to any degree, from having complaints and shaping their perceptions, cognitions, and preferences in a such way that they accept their role in the order of existing things, to see or imagine alternative to them, or to see it as natural and unchangeable?" (Lukes, 2005, p. 24).
}

This approach to power raises the question: how are arbitrary hierarchical relationships constructed so that they appear inevitable, natural, and therefore unquestionable?

Thus, according to Tikly (1999), in terms of organizations in the education sector, there is a dominant perspective to be adopted, which has subtly forced general obedience to its criteria and the patterns developed in central countries. Therefore, there is a reinforcement of the problem of domination in the management field, with countries like the United States and the United Kingdom exerting an influence on less developed or peripheral countries, such as emerging countries.

\section{Globalization and management education}

The study of the phenomenon of partnerships between international HEl on either side of the center-periphery division, within the context of management graduate courses, should consider that a program such as the IMPM, which has a globalized and multicultural purpose, needs to be embedded in what Santos (2006) has identified as the need for global action, but which, in fact, takes place through local or localized production.

In this sense, Santos (2006) makes a distinction between the two main forms of globalization production. Globalized localism is the process by which a certain phenomenon is successfully globalized, whether it be a multinational's worldwide activity, the transformation of the English language into a lingua franca, the globalization of American fast food or popular music, the adoption of programs such as MBAs regarding international management education, or the worldwide adoption of the same intellectual property, patent or telecommunications laws promoted aggressively by the US and other central countries. In this form of globalization production, what is globalized is the winner of a struggle to appropriate or value resources or recognize hegemonic, cultural, racial, sexual, ethnic, religious or regional differences. This victory translates into the ability to dictate the terms of integration, competition and inclusion (Santos, 2006).

The second process of globalization, called localized globalism, consists of a specific impact on local conditions which is produced by transnational practices and imperatives stemming from globalized localisms. To respond to these transnational imperatives, local conditions are disintegrated, oppressed, excluded, disorganized, and eventually restructured as subaltern inclusion. These localized globalisms include the elimination of traditional trade and subsistence farming, the creation of free trade enclaves or zones, and the massive destruction and deforestation of natural resources in order to pay off external debt. Accordingly, much of this subject refers to the different nuances of subalternity to which peripheral countries will be subjected within the scope of an international management education program (Santos, 2006).

By the same token, within the discussion of the relation between peripheral and central countries, Alcadipani (2017) defends the need to recover the concept of sociological reduction, created by the Brazilian sociologist Guerreiro Ramos in the 1950s. In the concept of sociological reduction, there is a critical, and even anti-colonial, attitude that argues that knowledge from the center is above all considered subsidiary and, as such, must be rethought in local forms before being assimilated (Ramos, 1984).

Based on this argument, Ramos (1984) postulates that all Brazilian development took place under the aegis of colonial subordination, which would not be different in relation to management issues. In this case, the creation of knowledge takes place in the central countries (USA and the United Kingdom) and, more specifically, in the Anglo-Saxon language, and is, then, disseminated to peripheral countries (Alcadipani, 2017) through a movement of 'cultural imperialism'.

Sociological reduction, in its last version (Ramos, 1984), meant, in a summarized way, that it should be seen as: (1) a method for the assimilation of foreign social thought in Brazil; (2) an attitude that allows people to overcome limitations that obstruct their freedom and autonomy; (3) a way of supplanting the place of a peripheral or colonized country with regard to academic management thinking. 
When it comes to the relationship established between the IMPM and the Brazilian HEI, analyzed through the lenses of sociological reduction, it is necessary to ask whether it will be accompanied by social transformation, and whether it will be supported by a system of education of its own. This system should be capable of creating its own patterns, not only importing the established patterns imposed long ago by central countries. To accomplish this, it is important to reflect on the following questions: should peripheral countries, which have now become integrated into international management education programs, choose to participate in such a program? Or have they always been "chosen"? Or what was the relationship involved in the establishment of the partnership from the perspective of those involved? These are the questions that have guided our research.

\section{METHODOLOGICAL APPROACH}

This study adopts a qualitative approach of an interpretative and critical nature (Alvesson \& Skoldberg, 2000). This choice was based on some of our assumptions such as the increasing complexity of this phenomenon in the face of globalization and the speed with which changes are taking place in the area of international management. As emphasized by Miles and Huberman (1994), social studies occur within the real world and have real impacts on people's lives and social dynamics and are constantly undergoing transformation.

In this study, we use three primary and secondary data sources: (i) (i) interviews with faculty and administrative staff, both from the IMPM and from the local IHE, as well as students from three classes held on Brazil, with semi-structured scripts; (ii) longitudinal documentary analysis; and (iii) direct observation during the Brazilian module. This set of data allowed us to avoid an analysis based on only one source, generating an approximate triangulation (Jick, 1979).

The interviews were conducted in the year of 2014 and 2015 in Rio de Janeiro. Altogether, 96 interviews were held during this period, however, considering the approach of this paper, eight of them were selected and analyzed. The selection of our interviewees was intentional, and they involved eight in-depth personal interviews with current members of the IMPM program linked to the formation, structuring and establishment of local partnerships, in addition to the members of the Brazilian HEI with which the partnership was established in 2012. According to Thiry-Cherques (2009), the saturation point usually occurs between the $6^{\text {th }}$ and $12^{\text {th }}$ interview, which made it reasonable to conclude the study with eight interviews.

Our documentary analysis was based on two types of documents that were collected: (i) internal documents such as - official IMPM documents, websites, handouts, historical records, contracts with other partner institutions, strategic planning, course pictures, demographic profiles of participants over time, and (ii) public domain documents such as - press surveys on IMPM, free testimonials on public domain media, alumni and partner websites, and blogs and academic information about the program.

This data was essential, since it provided us with a richer contextualization of the program and increased the reliability of the data obtained through the interviews, since documents "are products 'in time' and significant components of daily life that complement, complete, and compete with narrative and memory" (Spink, 1999, p. 126).

The results of the observations were added to a field diary that the researchers kept to report their observations on the issues investigated during this study (Czarniawska, 2008; Lofland \& Lofland, 1995).

Except for the appointment of the program's founder, Henry Mintzberg, who authorized the exposition of his name and his testimony, all of the other interviewees, faculty members and program and local institution directors had their identities preserved. Nevertheless, the role of the interviewees is informed in each speech, being them directors or coordinators from the program in the partner institution (D); professors or other faculty members (P); members of staff (M); and students (S).

The interviews were transcribed and analyzed, as well as all of the documents, observations and field notes. This entire set of data was submitted to thematic codification, in predetermined categories, to identify themes (Miles \& Huberman, 1994).

Therefore, with this scenario in mind, it was from the theoretical framework and the research question that a priori two categories were constructed that allowed us to identify and determine the problems related to the collected data: 'Globalization and management education' and 'The introduction of emerging countries into the IMPM agenda'. 


\section{ANALYSIS AND DISCUSSION OF THE RESULTS}

Above all, in terms of the presentation of IMPM's characteristics, it is important to emphasize its typicality. According to its characteristics, the program can easily be considered a classic master's degree course, adhering to the standards of an international MBA, offered by central countries, since its academic and administrative base of operations is in Canada and the United Kingdom. In addition, the course is given entirely under the aegis of the English language. It should also be noted that in 2016, the program received international recognition as one of the best international master's courses by the Global Focus report, conducted by the European Foundation for Management Development (EFMD) (Management Development Network).

Thus, the IMPM assumes a position partially divergent from this image which it reinforces in its institutional discourse, that it has no origin in the United States, and is not or may not be considered an MBA. In fact, the program - despite its closeto-center position due to its Anglo-Saxon origin maintained by its links with Canada and the United Kingdom - advocates a reflexive and disruptive approach to the standard model of dominant and orthodox MBA courses. This is not surprising given that the title of one of Mintzberg's books is Managers, not MBAs (Mintzberg, 2004).

The presentation of this section has been divided into the two categories listed above.

\section{Globalization and management education}

When investigating this first category, it is necessary to remember the initial objective, which was to verify how the process of establishing an international partnership has taken place since 2012 between the International Master's Program for Managers (IMPM), an international master's degree created in 1996 and directed by Henry Mintzberg, and a Brazilian HEI. Thus, we investigated the main motivations of the part of IMPM in choosing where to operate, given its special focus on peripheral countries, as well as how its internationalization process developed over time and, specifically, the way in which the relationship with the local partner in Brazil was established.

It should also be noted that, within the program's lifetime there have been some changes in the international partnerships. IMPM used to be present in countries such as Japan and France, for example, but has stopped working with them in favor of other countries such as Brazil and China. So, when the program's founder, Henry Mintzberg, was asked what his motivation was for the creation and implementation of IMPM as an essentially international project, his response was:

[...] "So, I think a good program is one that brings together people from different countries. The key to seeing our best features is not being global but being "part of the world"".

[...] "We do not want people to have a global mold, all the same. We want them to be individually from the world. We want them to understand other worlds and to penetrate them, deeply. [...] So I think this was the great incentive to make it international from the start."

In this excerpt, it is possible to perceive Mintzberg's initial willingness to promote an international program, without prejudice to local issues, which reinforces his theoretical argument. Documental sources such as books, articles, websites and official program documents since the mid-1990s reflect this international arrangement (Mintzberg, 2004).

Although the documents indicate that its purpose is to integrate, it is possible to argue to what extent a program from dominant countries can act without applying pressure on peripheral countries, without representing the threats exposed by Santos $(2003,2006)$ in the context of the globalized localism and localized globalism phenomena. That is, is this just the program's intention to be a global program, or is it really possible to preserve all the particularities of various "parts of the world" in an equitable manner?

In its genesis, the program was thought out in a way that was minimally aligned with the precepts of sociological reduction (Ramos, 1965), which presupposes the respect and the need for adaptations to local patterns before the indiscriminate application of knowledge from the center. However, inside the actual content of the program, we can perceive the clear and dominating presence of knowledge flowing from the center. Consequently, the center has the power to determine how the knowledge in question should be diffused, which by itself, may already be enough to demonstrate its domination and asymmetry (Alcadipani, 2017). 
Corroborating this vision, here is the testimony of another member of the faculty who has been present in the administration of the IMPM since its creation:

For the term "global managers", we attached the definition of managers who were the gods who drove globalization, and I think there was a sense within the program that this was a process that made the whole world fit into an American model. And the concept of "managers of the world", by contrast, we attached the definition that managers should understand that there were many ways of doing things in the world (P.1).

Within this testimony, it becomes clear that the IMPM was born and is guided by the idea, at least in theory, of a program that tries to develop a symmetrical or less asymmetrical relationship between 'Anglo-Saxon' countries and emerging countries which "can be as relevant as the global ones". On the other hand, it must be considered that, from the perspective of power that contemplates the definition of domination, it is never easy or even possible for the actors involved in the web of international relations to maintain an awareness and control that will guarantee less asymmetric interactions (Fleming \& Spicer, 2014).

Another aspect analyzed in this category concerns the choice not only of countries, but of specific cities for the establishment of local partnerships. According to Held, MCgrew, Goldblatt and Perraton (1999), observing phenomena that occur in large cities in peripheral and central countries can reduce the level of local characteristics, since large cities experience an approximation and pasteurization due to their subjection to the influence of global habits.

In this way, the intentions and concern with the choice of venues, cities and partner institutions within the establishment of the internationalization project of the program can be understood from this passage of Mintzberg's interview:

I was the one who lobbied for Brazil and for Rio. I said, São Paulo, no, I do not want to go to Sao Paulo. I said clearly, we have to go to Rio. [...] If we were in SP, we would have a lot more of the conventional business thinking that we have everywhere. [...] We are in Montreal, not in Toronto. Toronto is the business center. We are in Bangalore, which reflects, in part, my anti-establishment (against the pre-established) view of the world, too.

It is, thus, perceived that a place extends beyond the context of a country, or its cultural stereotype. Moreover, it appears that the IMPM considers this issue in its choices. Mintzberg made clear from his testimony that the places where the partnerships have been established are chosen in a manner consistent with the guiding principles of the program, that is, with intention of privileging his heterodox view of management. This is evident when he expresses his expectation of finding in Rio de Janeiro particularities that stand out from the global or pasteurized context of mainstream management. This point reinforces that, in principle, and in theory, the program intends to consider local issues more strongly (Held et al., 1999; Santos, 2006).

Regarding the possibility of establishing less asymmetric power relationships in its internationalization process, there are other interviews which state:

[...] So, if you go back to the beginning, the program was designed by people from McGill, INSEAD and Lancaster. That is, there was absolutely no emergent country within it [...] Whether it was India, Brazil or China, the idea was that cultural differences were an important part of the appreciation of management and management education. But the central ideas of how the program originated really did not have a very systematic view on these emerging economies (M.1).

In this extract, it is possible to observe traces that the program was developed by academics from central countries. Even with the explicit intention of providing a balanced experience among several places, these initial formulators dealt, from the beginning, with this question in the sense of experimenting the difficulties of whether to maintain or not to maintain unbalanced relationships in the management education sector. 


\section{The introduction of peripheral countries}

In the analysis of the second category, which addresses the introduction of peripheral countries into the IMPM agenda, we have sought to understand how the people involved in the internationalization of the program described these planning activities and their processes of action. The focus was on processes related to the most recent changes that have occurred in the last four years of the university partnerships, and specifically the case of Brazil.

First, it should be made clear that most international master's programs have practiced the same model in terms of the internationalization process and the choices of emerging countries through the establishment of partnerships. In this way, IMPM cannot be said to be a pioneer in its proposal, at least in relation to its current position, since three of its five modules operate in Brazil, China and India.

The testimony of a governing body member of the partner institution in Brazil recalls part of the history of the negotiation process, as well as the interviewee's perception of their conduct.

I believe that educational institutions and universities are organizations that organize themselves out of chaos, into emerging and unplanned processes [...] this process derives from four factors: opportunity, actors, problems and solutions. And I believe that in this case exactly this pattern has occurred (D.1).

The same respondent comments on the question of the program's interest in establishing the local partnership, considering that the IMPM is internationally recognized as linked to institutions of central countries, but with an apparent discourse of interest and respect for local characteristics (Alcadipani, 2017; Fleming \& Spicer, 2007, 2014).

I have doubts that they are really so interested in local issues. Let's split up. I think that the IMPM is a case in point, and there are other programs, like EMBA, Gemba, and several others, but in most of them, I see this as a way to create a product that is interesting, works as a marketing feature, and sells the product. That is, holding the international modules in several countries, and in this case emerging countries, have worked as an attraction (D.1).

This passage can be contrasted with the testimony of an IMPM leader who recalls the establishment of the program's international partnerships, the changes that have come with time, and their reasons for the progressive tilt towards peripheral countries.

I think the world was very different at the beginning of the program: 17 years ago, when the IMPM was created, Japan and South Korea were very important participants in the world, and so the logic of the five members was partly the result of contacts and of who were perceived as being the dominant players in the world. Then, the opportunity arose when two schools gave up [...] it was the case of INSEAD in France and also the South Koreans and the Japanese.

[...] INSEAD had a change of board and a different strategy. There was some political change in the situation in South Korea and the school was not allowed to do the IMPM again. We definitely needed to bring in new, rapidly developing countries. And, of course, China and Brazil were obvious participants. They were the two most obvious participants because of the importance of their rapid growth in the world. And this was a great opportunity for us not only to be (active) in the North, not only among former dominant participants, but also by bringing on two new members with totally different mentalities (D.2).

First of all, this statement draws attention to the fact that Japan and France wanted, spontaneously, to leave the program for different reasons. From this moment on, the IMPM had to seek new partnerships and it seemed natural that the choice should be made towards peripheral countries, specifically China and Brazil. That is, there was no identification of a specific moment in which the IMPM's management stopped and deliberately planned the partner exchange or identified the need to make this change with a premeditated intention of choosing new and specific partners (Held et al., 1999; Zadja, 2005).

Secondly, the fact that the interviewee explicitly expresses that bringing on two more partners, who were not part of the dominant players block - Brazil and China - would be more appropriate to the concepts and program purposes of expanding minds and bringing in local management elements. It was hoped that, in this way, it would be possible to add local knowledge to the theme in order to enrich the experience of all those involved, including the faculty, participants and organizations. 
However, a relevant fact must also be observed. Although much has been said about the need to maintain and respect local traits in a less asymmetric relationship of power, it has been found that the exchange of international partners over the course of almost twenty years has not resulted in a change in the IMPM modules' mindsets. For example, when France was exchanged for Brazil, it meant the change of the mindset of this module. Therefore, if the intention of the program in its internationalization process was to emphasize local experiences, both in cultural terms and in terms of knowledge management, it seems unlikely that countries as distinct as France and Brazil could be accommodated naturally within the same perspective (in this case, the mindset related to 'action'). Similarly, switching from Japan to China could have been questioned as to the continuity of the 'collaboration' mindset.

In fact, it would be possible to question why the central axis of the mindsets for more than twenty years was maintained: United Kingdom/ reflection and Canada/ analysis on one hand, and India/ worldview on the other. It is also necessary to ask whether, in this continuity, an international division in the production of knowledge, in which the center produces science, is not implicit, while the periphery produces culture (Mignolo, 2011, 2017). Now, reflection and analysis are centrally linked to the production of knowledge, and within this logic, by maintaining the production of science in the Anglo-Saxon world, it would make no difference whether another part of the globe would learn a little local culture from the 'world vision', 'collaboration' and 'action' mindsets. In other words, the very allocation of mindsets would be contrary to the logic of building the IMPM as a master's program differentiated from the Anglo-Saxon mainstream.

\section{FINAL CONSIDERATIONS}

The aim of this article is to verify how the internationalization strategy of the IMPM, the international master's degree of Henry Mintzberg has occurred, and, within this process, analyze how the construction of the partnership between the IMPM and a Brazilian HEI was established in 2012. Within this scope, we have sought to understand education as a geopolitical act. However, in taking this approach, we must also consider that education, as it has been practiced over the past few last decades, has been situated within a system that operates based on an unequal power relationship within the center-periphery divide.

Hence, in contemplating this scenario, we need to consider how globalization has had a problematic impact on management education, focusing on the contemporary international changes of context that have led to the introduction of peripheral countries such as India, China and Brazil to the agenda of the IMPM. In order to do this, it is essential to verify whether the local education modules in these countries are supported by their own education systems, capable of creating and respecting local patterns, instead of only importing those already established and imposed by central countries.

Our study has enabled us to conclude that the peripheral countries, which are now part of the IMPM, and especially Brazil, did not choose to participate in the program. In fact, they were "chosen" by the program leadership, composed of core countries. Thus, once again selected or invited, it was possible to perceive that there was a repetition of a pattern, followed by the international education market that dominates the sector, and which imposes the same model of domination and asymmetry present in relations between nations on opposite sides of the center-periphery divide.

It has also been argued that the fact that the program has exchanged partners - France for Brazil and Japan for China - without having changed their mindsets, may be considered as a sign that it is not quite so simple to practice their own heterodox discourse. That is, the IMPM might not be as concerned as it claims to be with the local issues of the countries with which it develops its institutional relations.

Moreover, the results presented reflect that, even when discussing an international master's program, a differentiated discourse in terms of ideological positioning and management education fulfills an agenda imposed by the American and Eurocentric academic hegemony, in the sense of favoring the interests of central countries to the detriment of the less developed or "peripheral" countries. After all, according to the logic imposed by the central countries themselves, it is up to them to produce knowledge, and up to the peripherals to produce culture and folklore. 
We hope that the consideration of the internationalization of management education programs phenomena, from a critical perspective, may amplify the voices of peripheral countries and provide a better balance between the production and consumption of management knowledge in the contemporary world scene. It is necessary to work from the perspective of a more dialogical movement between center and periphery, where not only the cultural aspects of these countries are considered but also their production of knowledge.

Thus, the main contribution of this work is focused on providing a critical and reflective view of this phenomenon, bringing up corresponding questions for future research on management education, in a scenario that can goes beyond what is simply global, to be, a truly multi-site landscape of knowledge.

By the same token, it is important to reinforce that it is necessary to reflect on the expansion and internationalization of institutions and organizations that develop and disseminate knowledge systems around the world. This body of agents, such as universities, think tanks, research institutes, and others, are responsible not only for producing dominant knowledge, but also for legitimizing it and disseminating it, especially when the critical factors and the adaptations of these issues are not observed.

According to this pattern, it is perceived that it is through the process of globalization and the asymmetrical relations that develop on either side of the center-periphery division, that the pattern of consumption of dominant knowledge is modeled, creating practically a model of epistemic colonization. From the periphery of Brazil, we would like to stress the laws of sociological reduction in the findings of MOK on both sides of the center-periphery divide: all foreign knowledge is subsidiary, and it must be sociologically reduced before it can be applied to investigate local reality. This is valid no matter which side of the divide you are on. 


\section{REFERENCES}

Alcadipani, R. (2017). Reclaiming sociological reduction: Analysing the circulation of management education in the periphery. Management Learning, 48(5), 535-551.

Alcadipani, R., \& Faria, A. (2014). Fighting Latin American marginality in "international" business. Critical Perspectives on International Business, 10(1/2), 107-117.

Alcadipani, R., \& Rosa, A. (2011). From global Management to glocal Management: Latin America Perspectives as a counter-dominant management epistemology. Canadian Journal of Administrative Sciences, 28(4), 453-466.

Alvesson, M., \& Skoldberg, K. (2000). Reflexive Methodology: New Vistas for Qualitative Research. London, UK: Sage Publications.

Banerjee, S. (2017). Globalization and Human Rights: How Globalization Can Be a Tool to Protect the Human Rights. In C. Akrivopoulou (Ed.), Defending Human Rights and Democracy in the Era of Globalization (pp. 1-16). Hershey, PA: IGI Global.

Banerjee, S., \& Linstead, S. (2004). Masking subversion: neocolonial embeddedness in anthropological accounts of indigenous management. Human Relations, 57(2), 221-247.

Celano, A. C., \& Guedes, A. L. (2014). Impactos da globalização no processo de internacionalização dos programas de educação em gestão. Cadernos EBAPE.BR, 12(1), 45-61.

Clegg, S., Barrett, M., Clarke, T., Dwyer, L., Gray, J., Kemp, S. E., ... Marceau, J. (2006). Management Knowledge for the Future: Innovation, Embryos and new Pardigms. In S. Clegg, G. Palmer (Eds.). The Politics of Management Knowledge (pp. 190-236). London, UK: Sage.

Clegg S., \& Palmer, G. (1989). Introduction: Producing Management Kn, UKowledge. In S. Clegg, \& G. Palmer (Eds.), The Politics of Management Knowledge (pp. 1-18). London: Sage.

Cummings, S. \& Bridgman, T. (2016). The limits and possibilities of history: How a wider, deeper, and more engaged understanding of business history can foster innovative thinking. Academy of Management Learning \& Education, 15(2), 250-267.

Cunliffe, A., \& Linstead, S. (2009). Introduction: teaching from critical perspectives. Management Learning, 40(1), 5-9.

Czarniawska, B. (2008). A Theory of Organizing. Cheltenham, UK; Northampton.

Faria, A. (2011). Repensando redes estratégicas. Revista de Administração Contemporânea, 15(1), 84-102.

Fleming, P., \& Spicer, A. (2007). Contesting the corporation: Struggle, power and resistance in organizations. Cambridge, UK: Cambridge University Press.

Fleming, P., \& Spicer, A. (2014). Power in management and organization science. The Academy of Management Annals, 8(1), 237-298.

Held, D., MCgrew, H., Goldblatt, D., \& Perraton, J. (1999). Global transformations: politics, economics and culture. Cambridge, UK: Polity Press.
Hurrell, A. (2010, January). Brazil and the Global Order. Current History, 109(724), 60-66. Retrieved from https://doi.org/10.1525/ curh.2010.109.724.60

Jick, T. D. (1979). Mixing qualitative and quantitative methods: triangulation in action. Administrative Science Quarterly, 24(4), 602-611.

Lofland, J., \& Lofland, L. (1995). Analyzing Social Setting: A guide for qualitative observation and analysis. London, UK: Thomson.

Lukes, S. (2005). Power and the Battle for Hearts and Minds. Millennium, 33(3), 477-493.

Mignolo, W. D. (2011). The Global South and World Dis/Order. Journal of Anthropological Research, 67(2), 165-88.

Mignolo, W. D. (2017). Coloniality is far from over, and so must be decoloniality. Afterall: A Journal of Art, Context and Enquiry, 43(1), 38-45.

Miles, M. B., \& Huberman, A. M. (1994). Qualitative Data Analysis. London, UK: Sage Publications.

Mintzberg, H. (2004). Managers not MBAs: A hard look at the soft practice of managing and management development. San Francisco, CA: Barrett-Koehler.

Mintzberg, H., \& Gosling, J. (2002). Educating Managers beyond borders. Academy of Management Learning and Education, 1(1), 64-76.

Mir, R., \& Mir, A. (2013). The colony writes back: Organization as an early champion of non-Western organizational theory. Organization, 20(1), 91-101.

Murphy, J., \& Zhu, J. (2012). Neo-colonialism in the academy? AngloAmerican domination in management journals. Organization, 19(6), 915-927.

Pfeffer, J. (2004) Managers not MBAs: A hard look at the soft practice of managing and management development. Administrative Science Quarterly, 49(3), 476-479.

Ramos, A. G. (1984). A redução sociológica (4th ed.). Rio de Janeiro, RJ: Tempo Brasileiro.

Santos, B. S. (2003). Reconhecer para libertar. Rio de Janeiro, RJ: Civilização Brasileira.

Santos, B. S. (2006). Globalizations. Theory Culture Society, 23(23), 393-399.

Soudien, C. (2005). Inside but below: The puzzle of education in the global order. In J. Zajda (Ed.), International Handbook on Globalization, Education and Policy Research. Global Pedagogies. Amsterdam, The Netherlands: Springer.

Spink, P. (1999). Reforming the State: Managerial Public Administration in Latin America. London, UK: Lynne Rienner Publishers.

Tikly, L. (1999). Post-colonialism and comparative education. In: C. Soudien, P. Kallaway, \& M. Breier (Eds.), Education, Equity and Transformation (pp. 603-621). Dordrecht, The Netherlands: Dordrecht Kluwer Academic Publishers. 
Wanderley, S., \& Barros, A. (2018). Decoloniality, geopolitics of knowledge and historic turn: towards a Latin American agenda. Management \& Organizational History, 14(4), 1-19
Zajda, J. (2005). Globalization, education and policy: changing paradigms. In J. Zajda (Ed.), International Handbook on Globalization, Education and Policy Research. Global Pedagogies. Amsterdam, The Netherlands: Springer.

Ana Christina Celano Teixeira

ORCID: https://orcid.org/0000-0001-9721-0626

Ph.D. in Administration from Fundação Getulio Vargas (FGV EBAPE); Full professor at IBMEC. E-mail: ana.teixeira@ibmec.edu.br

\section{Sergio Wanderley}

ORCID: https://orcid.org/0000-0002-9248-5214

Ph.D. in Administration from Fundação Getulio Vargas (FGV EBAPE); Associate professor at the University of Grande Rio (UNIGRANRIO).

E-mail: sergiow.gaz@terra.com.br

\section{Ana Beatriz Moraes}

ORCID: https://orcid.org/0000-0002-1252-2872

D.Sc. in Innovation Management from Federal University of Rio de Janeiro (EQ/UFRJ); Full professor at IBMEC. E-mail: ana.moraes@ibmec.edu.br

\section{Bianca Sá}

ORCID: https://orcid.org/0000-0002-0177-6869

Master in Administration from IBMEC-RJ; Ph.D. student in Administration at Fundação Getulio Vargas (FGV EBAPE). E-mail: bassisrangel@gmail.com 